\title{
Test decyzji administracyjnej i dopuszczalność modyfikacji trybu jej wydawania aktem podustawowym
}

\author{
Wyrok Naczelnego Sądu Administracyjnego z dnia 19 marca 2019 r., \\ I OSK 1222/17
}

Przyznanie przez jednostkę samorządu terytorialnego stypendiów, nagród i wyróżnień, o których mowa w art. 31 ustawy z dnia 2 czerwca 2010 r. o sporcie, nie następuje $w$ formie decyzji w rozumieniu art. 104 k.p.a.

\author{
Aleksander Jakubowski \\ Uniwersytet Warszawski \\ ajakubowski@uw.edu.pl \\ ORCID: 0000-0002-5937-9591
}

https://doi.org/10.26881/gsp.2020.2.11

\section{Glosa}

1. Sześćdziesiąta rocznica uchwalenia kodeksu postępowania administracyjnego ${ }^{1}$ skłania do refleksji przede wszystkim nad tymi koncepcjami i problemami prawnymi, z którymi przez te lata się musiały - i wciąż muszą - mierzyć nauka i praktyka postępowania administracyjnego. Idzie tu zatem o zagadnienia pierwszorzędne, niezmiennie potwierdzające swoją aktualność. Do nich należy niewątpliwie kwestia kwalifikowania danego fenomenu, będącego przejawem działania administracji publicznej, jako decyzji administracyjnej. Wyznacza bowiem zakres przedmiotowy normowania kodeksu postępowania administracyjnego, zgodnie z jego art. 1 pkt 1 i 2. Mimo upływu lat i znaczącego dorobku doktryny i judykatury na tym gruncie - brak jest wciąż w tym obszarze konsensusu, który byłby konsekwentnie realizowany w praktyce. Symptomatyczne dla tego stanu rzeczy jest właśnie orzeczenie będące przedmiotem niniejszej glosy. Omawiany wyrok ${ }^{2}$ Naczelnego Sądu Administracyjnego (NSA) jest przy tym interesujący z jeszcze jednego względu - stwarza mianowicie przyczynek do rozważenia

\footnotetext{
1 Ustawa z dnia 14 czerwca 1960 r. - Kodeks postępowania administracyjnego (tekst jedn.: Dz. U. z 2020 r., poz. 256 ze zm.; dalej: k.p.a.).

2 Wyrok NSA z dnia 19 marca 2019 r., I OSK 1222/17, Centralna Baza Orzeczeń Sądów Administracyjnych (CBOSA).
} 
dopuszczalności modyfikowania lub wyłączania przepisów k.p.a. przez przepisy podustawowe, w świetle przyjętych w teorii prawa reguł kolizyjnych.

2. Glosowane orzeczenie miało za przedmiot akt prawa miejscowego - uchwałę rady gminy w sprawie zasad i trybu przyznawania oraz pozbawiania stypendiów sportowych - jednak w związku z nią sąd poczynił uwagi dotyczące formy rozstrzygnięcia, w jakiej jednostki samorządu terytorialnego przyznają stypendia, nagrody i wyróżnienia sportowe. W tym przypadku NSA przyjął, że działanie to nie przybiera formy decyzji administracyjnej.

Sąd podniósł, że skoro w art. 32 ust. 5 ustawy o sporcie ${ }^{3}$ prawodawca wprost postanowił, że „przyznanie, wstrzymanie oraz pozbawienie stypendium sportowego przez ministra właściwego do spraw sportu następuje w drodze decyzji", zaś takiej regulacji nie zawiera art. 31 tej ustawy, przewidujący możliwość przyznawania stypendiów, nagród i wyróżnień przez jednostki samorządu terytorialnego, to przyznanie ich nie następuje w formie decyzji administracyjnej w rozumieniu art. 104 k.p.a. Jak dodał NSA, „ustawa nie przewiduje także stosowania przepisów K.p.a." Sąd odnotował, że w myśl art. 31 ust. 3 ustawy o sporcie w przypadku powzięcia zamiaru przyznawania takich stypendiów, nagród i wyróżnień, organ stanowiący jednostki samorządu określa tryb ich przyznawania w uchwale. Tym samym w ocenie NSA, to jednostkom samorządu terytorialnego przyznano kompetencje do określenia procedury związanej z przyznaniem stypendium. Sąd ten spostrzegł końcowo, że „określenie rozstrzygnięcia organu wykonawczego mianem decyzji nie oznacza, że jest to decyzja w rozumieniu K.p.a., akt załatwiający w sposób władczy sprawę administracyjną, podlegający rygorom procedury administracyjnej, w tym trybom zaskarżania i kontroli sądowej".

3. Rozważania na temat przedmiotowego orzeczenia przychodzi rozpocząć od oceny, czy zasadnie NSA wykluczył uznanie za decyzję administracyjną rozstrzygnięcia w sprawie samorządowego stypendium sportowego.

Doktryna decyzji administracyjnej jest w swych założeniach prosta, by nie rzec banalna. Została ona ukuta już u zarania odtworzonego sądownictwa administracyjnego w Polsce 4 . Zwięźle ujął ją Sąd Najwyższy (SN) stwierdzając ${ }^{5}$, iż „powszechnie uznana dyrektywa interpretacyjna przyjmuje, że o kwalifikowaniu danego aktu prawnego jako decyzji nie decyduje nazwa występująca w przepisie prawnym czy w nagłówku pisma, lecz wyłącznie jego treść i wynikający z niej merytoryczny charakter aktu6. Kryterium kwalifikującym dany akt organu jako decyzję jest władcze i jednostronne

3 Ustawa o sporcie z dnia 25 czerwca 2010 r. (tekst jedn.: Dz. U. z 2019 r., poz. 1468 ze zm.; dalej: ustawa o sporcie).

4 Nie znaczy to jednak, że wówczas była bezsporna. Przegląd stanowisk prezentuje W. Taras [w:] idem, Glosa do wyroku SN z dnia 28 listopada 1990 r., III ARN 30/90, OSP 1992, z. 5, s. 237-239. Rzecz jasna, doktryna ta bazuje na funkcjonujących już wcześniej w nauce koncepcjach.

5 Uchwała SN z dnia 5 lutego 1988 r., III AZP 1/88, OSPiKA 1989, z. 3, poz. 59.

6 Jak stwierdził SN w wyroku z dnia 18 października 1985 r., II CR 320/85, OSNC 1986, nr 10, poz. 158, użycie tej czy innej nazwy nie ma znaczenia dla charakteru prawnego danego aktu jako decyzji, jeżeli jest to zgodnie $z$ art. 104 k.p.a. akt rozstrzygający merytorycznie indywidualną sprawę należącą do właściwości organu administracji państwowej. Podobnie NSA w postanowieniu z dnia 11 lipca 1984 r., SA/Wr 309/84, ONSA 1984, nr 2, poz. 61. 
rozstrzygnięcie kształtujące indywidualną sytuację prawną jednostki, niepodporządkowanej organowi bądź poprzez przyznanie lub odmowę przyznania jej uprawnień, bądź nałożenie obowiązków bądź stwierdzenie istnienia prawnego uprawnienia lub obowiązku w sferze prawa administracyjnego czy finansowego ${ }^{7}$. Tę generalną dyrektywę należy także odnieść do tych przypadków, w których ustawodawca nie sprecyzował formy prawnej załatwienia indywidualnych spraw"8. Wywód ten stanowi w istocie rozwinięcie myśli wyrażonej przez NSA już w wyroku z 1983 r., że jeżeli strona posiadająca w tym interes prawny wystąpiła do organu administracji państwowej o załatwienie sprawy indywidualnej, a mające $w$ niej zastosowanie normy są normami prawa administracyjnego, to ustalenie ich wiążących konsekwencji względem indywidualnie określonych podmiotów w konkretnej sprawie powinno odbywać się w formach prawnych właściwych dla działań tych organów. Skoro zaś przepis prawa materialnego nie określa takiej formy konkretyzacji sytuacji prawnej obywatela, to wówczas organ powinien dokonać jej w formie decyzji administracyjnej, która umożliwiając instancyjną i ewentualnie sądowoadministracyjną kontrolę rozstrzygnięcia, najlepiej chroni występujące w sprawie interesy: indywidualny i społeczny ${ }^{10}$.

Ten - oparty na weryfikacji cech badanego aktu - sposób ustalenia bytu decyzji administracyjnej znalazł potwierdzenie w orzecznictwie NSA w węzłowym wyroku z 1994 r. ${ }^{11}$ Podkreślono w nim, że o istocie aktu prawnego przesądza jego treść, a nie forma, wobec czego pismo niemające formy decyzji jest decyzją administracyjną, jeżeli pochodzi od organu administracji, skierowane jest na zewnątrz i w sposób władczy rozstrzyga o prawach lub obowiązkach prawnych osób (fizycznych lub prawnych) w sprawie indywidualnej, choćby dla rozstrzygnięcia takiego brak było podstawy prawnej.

Również doktryna od dziesięcioleci przyjmuje, że decyzja administracyjna jest zewnętrznym aktem władczym (jednostronnym) organu administracji publicznej (organu „administrującego"), skierowanym na wywołanie skutków prawnych, określającym sytuację prawną konkretnie oznaczonego podmiotu prawnego w konkretnie oznaczonej sytuacji (sprawie) ${ }^{12}$; rozstrzyga sprawę administracyjną lub kończy ją w danej

\footnotetext{
7 Stanowisko to potwierdził SN w uchwale z dnia 18 listopada 1992 r., III AZP 20/92, OSNCP 1993, nr 3, poz. 27, w której jest już mowa o jednolitym orzecznictwie na gruncie wskazanej koncepcji.

8 „Brak wyraźnego określenia prawnej formy załatwienia sprawy (...) nie może przesądzać o tym, że sprawa ta nie podlega załatwieniu w drodze decyzji administracyjnej" - zob. uchwała NSA z dnia 28 maja 2001 r., OPK 10/01, ONSA 2001, nr 4, poz. 159.

9 Wyrok NSA z dnia 14 czerwca 1983 r., SAB/Wr 6/83, PiP 1984, z. 8, s. 150 i n., z glosą J. Grabowskiego.

10 Materiały do nauki prawa administracyjnego, red. M. Kulesza, Warszawa 1985, s. 244-249. Zob. też NSA w wyroku z dnia 13 lipca 1983 r., II SA 983/83, ONSA 1983, nr 2, poz. 57; wyrok NSA z dnia 31 sierpnia 1984 r., SA/Wr 430/84, OSP 1986, z. 9-10, poz. 176, z glosą S. Biernata.

11 Wyrok z dnia 21 lutego 1994 r., I SAB 54/93, OSP 1995, z. 11, poz. 221, z glosą B. Adamiak i J. Borkowskiego.

12 Por. R. Orzechowski [w:] Kodeks postępowania administracyjnego. Komentarz, red. J. Borkowski, Warszawa 1985, s. 24; Z. Janowicz, Kodeks postępowania administracyjnego. Komentarz, Warszawa-Poznań 1987, s. 30; M. Bogusz, Zaskarżenie decyzji administracyjnej do Naczelnego Saqu Administracyjnego, Warszawa 1997, s. 79; C. Martysz [w:] idem, G. Łaszczyca, A. Matan, Kodeks postępowania administracyjnego. Komentarz, t. 1, Art. 1-104, Warszawa 2010, s. 30-31; K. Klonowski [w:] Kodeks postępowania administracyjnego. Komentarz, red. H. Knysiak-Sudyka, Warszawa 2019, s. 44-45.
} 
instancji ${ }^{13}$. Nie dziwi zatem, że definicję decyzji, proponowaną w projekcie przepisów ogólnych prawa administracyjnego z 2008 r. ${ }^{14}$ jako „jednostronny, władczy akt organu administracji publicznej rozstrzygający konkretną sprawę indywidualnego podmiotu nie wynikającą z organizacyjnego lub służbowego podporządkowania organowi, który go wydał, niezależnie od nazwy nadanej w przepisach temu aktowi" (art. 5 ust. 1 pkt 1) - Zbigniew Kmieciak określa mianem syntezującej poglądy doktryny ${ }^{15}$.

Niekiedy dodaje się - jako cechy decyzji administracyjnej - wydanie jej na podstawie przepisów prawa powszechnie obowiązującego i z zachowaniem wymaganej prawem procedury ${ }^{16}$, co trudno jednak uznać za elementy konstytutywne (materialne) pojęcia; wszak niezgodna z prawem decyzja administracyjna zachowuje swój charakter, wymagając ewentualnie eliminacji z obrotu prawnego. Gdyby przestawała być z tego tytułu decyzją administracyjną, konsekwentnie nieuzasadnione byłoby jej weryfikowanie przez pryzmat przepisów określających tę formę, co prowadziłoby ad absurdum ${ }^{17}$. Odnotować można również definicje określające decyzję administracyjną jako „oświadczenie woli” lub jako rozstrzygnięcie o wiążących konsekwencjach normy prawa administracyjnego ${ }^{18}$. To pierwsze jest o tyle mylące, że zwłaszcza w przypadku decyzji związanych trudno jest mówić o jakiejkolwiek „woli” organu ${ }^{19}$, z kolei cecha w postaci konkretyzacji norm prawnych nazbyt zawęża pojęcie decyzji, wyłącza bowiem poza jego nawias istniejące przecież decyzje administracyjne nieposiadające podstawy prawnej, o których mowa w art. $156 \S 1$ pkt 2 k.p.a., a zatem pozbawione normy, którą mogłyby konkretyzować.

Materialna koncepcja decyzji administracyjnej urzeczywistnia zasadę prawa do procesu na drodze administracyjnej oraz wynikającego z niego domniemania załatwiania spraw administracyjnych w formie decyzji administracyjnej. Barbara Adamiak wywodzi je z art. 2 Konstytucji ${ }^{20}$. Zasada prawa do procesu polega na przyznaniu jednostce prawa do obrony interesu prawnego w unormowanym przepisami prawa

13 Zob. E. Iserzon [w:] idem, J. Starościak, Kodeks postępowania administracyjnego. Komentarz, Warszawa 1961, s. 136.

14 https://www.rpo.gov.pl/pliki/12059280660.pdf

15 Z. Kmieciak [w:] Kodeks postępowania administracyjnego. Komentarz, red. idem, W. Chróścielewski, Warszawa 2019, s. 38.

16 J. Borkowski, B. Adamiak, Kodeks postępowania administracyjnego. Komentarz, Warszawa 2019, s. 29; R. Kędziora, Kodeks postępowania administracyjnego. Komentarz, Warszawa 2017, s. 38, s. 618; A. Wróbel [w:] idem, M. Jaśkowska, Kodeks postępowania administracyjnego. Komentarz, Warszawa 2016, s. 71; Z. Janowicz, Kodeks postępowania administracyjnego. Komentarz, Warszawa-Poznań 1987, s. 30. Por. też J. Borkowski, Decyzja administracyjna, Warszawa 1970, s. 92.

17 Na kwestię tę zwracał już uwagę M. Bogusz, Zaskarżenie..., s. 83-84.

18 Zob. C. Martysz [w:] idem, G. Łaszczyca, A. Matan, Kodeks..., s. 30-31.

19 Por. J. Borkowski, Decyzja administracyjna, Łódź - Zielona Góra 1998, s. 19-20.

20 B. Adamiak, Prawo do procesu w świetle regulacji prawa procesowego administracyjnego [w:] System Prawa Administracyjnego, t. 9, Prawo procesowe administracyjne, red. R. Hauser, Z. Niewiadomski, A. Wróbel, Warszawa 2017, s. 110. Krytyczny wobec tych koncepcji jest Z. Kmieciak, zob. idem, W poszukiwaniu modelu postępowania odpowiadajq̨cego naturze administracji publicznej, PiP 2015, nr 11, s. $10-12$. 
procesowego postępowaniu ${ }^{21}$, w tym za pomocą środków zaskarżenia'22, z zagwarantowaniem prawa do wysłuchania i czynnego udziału w ustaleniu stanu faktycznego ${ }^{23}$. Stąd w razie gdy norma prawa materialnego wymaga autorytatywnej konkretyzacji, a przepis prawa nie kształtuje stosunku materialnoprawnego za pomocą innej formy działania, obowiązywać ma zasada domniemania formy decyzji administracyjnej ${ }^{24}$.

Koncepcja materialna decyzji administracyjnej w istocie zdeterminowała w ostatnich dziesięcioleciach zakres stosowania kodeksu postępowania administracyjnego, wyznaczany jedynie ogólnie i niesamodzielnie przez jego przepisy początkowe. Sześćdziesiąta rocznica uchwalenia kodeksu rodzić może pytania o zasadność przyjmowania wskazanej idei, którą zdaje się podważać nie tylko glosowany wyrok, ale i część doktryny. W tej ostatniej odnotować należy głosy, że zakładanie formy decyzji administracyjnej nie jest już potrzebne czy celowe, a to z uwagi na poszerzenie właściwości rzeczowej sądów administracyjnych ${ }^{25}$. Argumentację tę można by było podzielić, gdyby ustawodawca stworzył formę alternatywą względem decyzji administracyjnej, której procedura stosowania byłaby odpowiednio zupełna i zapewniała gwarancje wymagane przez wywodzoną z art. 2 Konstytucji zasadę sprawiedliwości procesowej. Tak się jednak dotychczas nie stało, zatem odstępowanie od formy decyzji administracyjnej na rzecz bliżej niedookreślonej formy innego aktu czy czynności rodzić może wątpliwości co do zgodności z konstytucyjnymi wymaganiami państwa prawnego. Brak bowiem dostatecznego określenia procedury formułowania tych innych aktów czy czynności pozbawia sąd administracyjny wzorców kontroli, według których mógłby ocenić proceduralną legalność działania organu. W takim przypadku prawo do sądu staje się iluzoryczne. W tym kontekście warto zwrócić uwagę na zjawisko, które można określić jako „efekt bumerangu” - aby wyeliminować opisany brak, sądy stwierdzają, że gwarancje wynikające z zasad ogólnych k.p.a. „stanowią w istocie odbicie państwa prawnego (art. 2 Konstytucji)"26, a w konsekwencji i tak uznają je za pewien wzorzec kontroli legalnościowej również aktów czy czynności, w których przepisy k.p.a. mają nie mieć zastosowania. Nie można też pominąć problemów dość prozaicznych, np. związanych z doręczaniem innych niż wydawane w trybie k.p.a. aktów.

21 B. Adamiak, Prawo do procesu w świetle..., s. 109.

22 B. Adamiak, Prawo do procesu na drodze administracyjnej jako gwarancja realizacji zasady demokratycznego państwa prawnego [w:] Instytucje procesu administracyjnego i sq̨dowoadministracyjnego. Księga jubileuszowa dedykowana Prof. nadzw. dr hab. Ludwikowi Żukowskiemu, red. J. Posłuszny, Z. Czarnik, R. Sawuła, Przemyśl-Rzeszów 2009, s. 29.

23 B. Adamiak, Zagadnienie domniemania formy decyzji administracyjnej [w:] Podmioty administracji publicznej i prawne formy ich działania. Studia i materiały z Konferencji Naukowej Poświęconej Jubileuszowi 80-tych urodzin Profesora Eugeniusza Ochendowskiego, Toruń 2005, s. 16.

24 B. Adamiak, Prawo do procesu na drodze administracyjnej..., s. 33; eadem, Prawo do procesu w świetle..., s. 112.

25 Por. J.P. Tarno, Glosa do uchwały NSA z 12 grudnia 2005 r., II OPS 4/05, ZNSA 2006, nr 1, s. 150-151;

Z. Kmieciak [w:] Kodeks..., s. 39-40. Por. J. Borkowski, B. Adamiak, Kodeks..., s. 20.

26 Zob. postanowienie NSA z dnia 28 czerwca 2016 r., I OSK 1328/16, OSP 2017, z. 4, poz. 37 z glosą

W. Czerwińskiego. 
Rewersem stanowiska materialnego jest wciąż aktualna ${ }^{27}$ koncepcja formalna, zgodnie z którą o decyzji administracyjnej można mówić, jeżeli pismo posiada oznaczenie organu administracji wydającego akt, wskazanie adresata aktu, rozstrzygnięcie o istocie sprawy oraz podpis osoby reprezentującej organ administracji ${ }^{28}$. Jak wskazał $\mathrm{SN}^{29}$, brak niektórych składników decyzji w danym rozstrzygnięciu powziętym przez upoważniony organ, a określonych w art. 107 § 1-3 k.p.a., nie uzasadnia traktowania takiego rozstrzygnięcia jako innej formy działania administracji, gdyż „w wypadkach spornych należy przyjąć ogólne domniemanie działania w formie decyzji". Koncepcja materialna i formalna dopełniają się wzajemnie ${ }^{30}$, jednak ta pierwsza - jako zasadniczo szersza - powinna mieć rolę wiodącą.

Akt, jakim jest decyzja administracyjna, odróżnić należy materialnie od czynności, zwłaszcza materialno-technicznych. Dystynkcja opiera się nie na formie ${ }^{31}$, lecz na kwestii nakierowania bezpośrednio na wywołanie określonych skutków prawnych ${ }^{32}$. Cechę tę posiadają akty, brak jej zaś w przypadku czynności. Ponadto za decyzję administracyjną z woli ustawodawcy nie może być uznany rezultat milczącego załatwienia sprawy przez organ ${ }^{33}$.

Mając na uwadze powyższe, można skonstruować „test decyzji administracyjnej”. Sprowadza się on do odpowiedzi na następujące pytania:

1) czy przedmiot testu pochodzi od organu administracji publicznej, choćby w znaczeniu funkcjonalnym (podmiotu wykonującego pozasądowe i pozaprawodawcze zadania publiczne)?

2) czy przedmiot testu jednostronnie rozstrzyga o sytuacji prawnej (obowiązkach, uprawnieniach lub ich braku) innego podmiotu (tj. czy jest władczy)?

3) czy rozstrzygnięcie to wynika samo przez się (wywołuje skutki bezpośrednio) z przedmiotu testu (jest on aktem), a nie wskutek niego (nie jest czynnością materialno-techniczną) lub upływu czasu (nie jest tzw. milczącym załatwieniem)?

27 Zob. postanowienie NSA z dnia 14 lutego 2017 r., I OSK 211/17, CBOSA.

28 Zob. wyrok NSA z dnia 20 lipca 1981 r., SA 1163/81, OSPiKA 1982, z. 9-10, poz. 169, z glosą J. Borkowskiego; wyrok NSA z dnia 5 października 1982 r., II SA 969/82, ONSA 1982, nr 2, poz. 94; P. Gołaszewski, K. Wąsowski [w:] Kodeks postępowania administracyjnego. Komentarz, red. R. Hauser, M. Wierzbowski, Warszawa 2018, s. 14-15.

29 Wyrok SN z dnia 28 listopada 1990 r., III ARN 30/90, OSP 1992, z. 5, poz. 116.

30 A. Wróbel [w:] idem, M. Jaśkowska, Kodeks postępowania administracyjnego. Komentarz, Warszawa 2016, s. 72.

31 J. Starościak, Prawne formy i metody działania administracji [w:] System Prawa Administracyjnego, t. 3, red. T. Rabska, J. Łętowski, Wrocław 1978, s. 109.

32 Zob. uchwała NSA z dnia 26 czerwca 2014 r., I OPS 14/13, ONSAiWSA 2015, nr 1, poz. 2. Por. K. Ziemski, Indywidualny akt administracyjny - jego istota [w:] System Prawa Administracyjnego, t. 5, Prawne formy działania administracji, red. R. Hauser, Z. Niewiadomski, A. Wróbel, Warszawa 2013, s. 175; K.M. Ziemski, Indywidualny akt administracyjny jako forma prawna działania administracji, Poznań 2005, s. 100-107. J. Starościak twierdził z kolei, że czynności kształtują nowe stosunki prawne przez fakty, a akty administracyjne przez bezpośrednie tworzenie nowej normy obwiązującego porządku prawnego - idem, Prawne formy..., s. 109-110. Szerzej przegląd stanowisk na czynność jako prawną formę przedstawia Ł.M. Wyszomirski [w:] idem, Sqdowa kontrola innych niż decyzje i postanowienia aktów i czynności zakresu administracji publicznej, Warszawa 2018, s. 51-64.

33 Por. Z. Kmieciak [w:] Kodeks..., s. 37. 
4) czy rozstrzygnięcie to dotyczy istoty (art. $104 \S 1$ k.p.a.) konkretnej (niehipotetycznej, istniejącej) sytuacji adresata?

5) czy podmiot, o którego sytuacji prawnej akt rozstrzyga (adresat aktu), jest możliwy do określenia indywidualnie?

Odpowiedź twierdząca na wszystkie powyższe pytania oznacza, że ma się do czynienia z decyzją administracyjną.

Zwrócić warto uwagę na dwa elementy powyższego testu. Po pierwsze, dla uznania przedmiotu testu za decyzję administracyjną nie musi być on sformułowany zgodnie z przepisami prawa czy na ich podstawie. Legalność czy nielegalność przedmiotu testu jest irrelewantna dla jego kwalifikacji jako decyzji administracyjnej. Kwestia ta będzie dopiero determinowała rezultat ewentualnej kontroli decyzji. Dla wyniku testu nie ma też znaczenia, czy ustawodawca wykluczył w danej kategorii spraw stosowanie k.p.a. W istocie wyłączenie takie będzie dodatkowo potwierdzało wynik testu, gdyby bowiem przedmiot testu nie był decyzją administracyjną, wówczas wyłączenie k.p.a. byłoby zbędne, bezprzedmiotowe, a tak materialnie przedmiot testu jest decyzją administracyjną, jednak ustawodawca wyłącza stosowanie art. 1 pkt 1 lub pkt 2 k.p.a. przepisem szczególnym. Po wtóre, opisany test nie wymaga dla uznania jego przedmiotu za decyzję administracyjną, aby ów przedmiot był fizycznie zmaterializowany. Dopuszcza zatem decyzję administracyjną, która nie będzie ujęta na żadnym nośniku, lecz którą stwierdzać będziemy konkludentnie przez jej skutki. Godzi się wszak zauważyć, że sam k.p.a. dopuszcza decyzje administracyjne wydawane ustnie ${ }^{34}$, bez

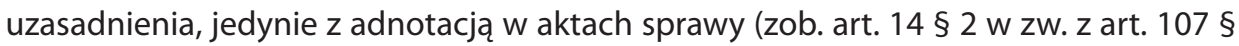
4 k.p.a.). Nieutrwalenie decyzji administracyjnej może być ocenione jako daleko idące naruszenie prawa, ale oznacza to, że musimy przedtem stwierdzić, iż w ogóle ma się do czynienia z decyzją administracyjną niezależnie od jej ujęcia fizycznego.

Aby potwierdzić, że do tak ustalonej decyzji administracyjnej stosuje się przepisy k.p.a., należy dodać jeszcze jeden element testu, wynikający z art. 3 k.p.a., w postaci pytania:

6) czy sytuacja prawna, o której akt rozstrzyga, nie odnosi się do relacji podległości służbowej lub organizacyjnej między organem administracji publicznej albo innej, w której ustawodawca wyklucza wyraźnie przepisem szczególnym stosowanie k.p.a.?

Spróbujmy zatem zastosować proponowany test do przypadku glosowanej sprawy.

Potwierdzić można, że przedmiot testu pochodzi od organu administracji publicznej, niewątpliwie organy jednostek samorządu terytorialnego się bowiem do nich zaliczają (art. 5 § 2 pkt 3 k.p.a.). Rozstrzyga on o tym, czy danemu podmiotowi przysługuje czy nie przysługuje uprawnienie do otrzymania stypendium, bez potrzeby uzyskania zwrotnej zgody tego podmiotu ani bez czynienia go dysponentem tego prawa, zatem jest to akt władczy i jednostronny. Przedmiot testu jest nakierowany na przyznanie lub odmowę przyznania stypendium, nie dochodzi zaś do tego jedynie wtórnie wskutek

34 Akt administracyjny może być bowiem aktem ustnym - zob. J. Starościak, Prawne formy..., s. 63. 
niego czy upływu czasu - jest zatem aktem. Dotyczy on istoty sprawy przyznania stypendium, nie zaś kwestii wpadkowych, i odnosi się do konkretnej sytuacji wyznaczonej osiągnięciami danego - określonego indywidualnie - podmiotu (adresata). Jednocześnie kwestia stypendium sportowego dla niego nie jest materią z zakresu podległości służbowej lub organizacyjnej względem organu rozstrzygającego sprawę. Oznacza to, że prawidłowa jest odpowiedź twierdząca na wszystkie pytania testu.

Tym samym rozstrzygnięcie w przedmiocie przyznania samorządowego stypendium sportowego jest decyzją administracyjną. Tak też było kwalifikowane w poprzedzającym glosowany wyrok orzecznictwie nie tylko wojewódzkich sądów administracyjnych $^{35}$, ale też i samego Naczelnego Sądu Administracyjnego, który wskazywał, że sprawa w przedmiocie przyznania, jak i odmowy przyznania stypendium sportowego dla osób fizycznych za osiągnięte wyniki sportowe na podstawie przepisu aktu prawa miejscowego, wydanego na podstawie szczegółowego upoważnienienia zawartego w art. 31 ust. 3 ustawy o sporcie, stanowi indywidualną sprawę administracyjną, której rozstrzygnięcie powinno nastąpić w drodze decyzji administracyjnej ${ }^{36}$. Tę linię orzeczniczą NSA obecnie zresztą wyraźnie kontynuuje wbrew tezie komentowanego wyro$\mathrm{ku}^{37}$. Przedstawione stanowisko nie budziło też wątpliwości doktryny ${ }^{38}$.

Podniesiony w glosowanym wyroku argument systemowy z porównania art. 32 ust. 5 - określającego jednoznacznie formę przyznania, wstrzymania oraz pozbawienia stypendium sportowego przez ministra - z art. 31 ustawy o sporcie, którego przepisy takiej formy wprost nie podają, nie wydaje się trafny. Skoro bowiem nie ma materialnej różnicy między decyzją o przyznaniu stypendium sportowego przez ministra i aktem w tym przedmiocie wydawanym przez organ jednostki samorządu terytorialnego - oba, jak wykazano, władczo rozstrzygają o istocie konkretnej sprawy przyznania stypendium sportowego indywidualnemu podmiotowi - to nie ma powodów do przypisywania im odmiennych form. Tę kwestię można skwitować znanym rozumowaniem abdukcyjnym: If it looks like a duck, swims like a duck, and quacks like a duck, then it probably is a duck (ang.) ${ }^{39}$. Jeżeli akt ma wszystkie cechy decyzji administracyjnej (a te można już wywieść, ustalając cechy decyzji stypendialnej ministra, będącej niewątpliwie decyzją administracyjną), to najprawdopodobniej jest decyzją

\footnotetext{
35 Zob. wyrok WSA w Lublinie z dnia 1 września 2011 r., II SA/Lu 579/11, CBOSA; wyroki WSA w Białymstoku z dnia: 14 kwietnia 2016 r., II SA/Bk 134/16, CBOSA; 24 maja 2016 r., II SA/Bk 170/16, CBOSA. 36 Wyroki NSA z dnia: 7 lutego 2019 r., II GSK 5072/16, CBOSA; 4 grudnia 2018 r., II GSK 1702/18, CBOSA. Por. jednak wyrok NSA z dnia 17 sierpnia 2017 r., II GSK 1041/17, CBOSA, w którym Sąd dopuścił uznanie omawianego aktu za formę, o której mowa w art. 3 § 2 pkt 6 ustawy z dnia 30 sierpnia 2002 r. - Prawo o postępowaniu przed sądami administracyjnymi (tekst jedn.: Dz. U. z 2019 r., poz. 2325; dalej: p.p.s.a.).

37 Zob. wyroki NSA z dnia: 28 sierpnia 2019 r., II GSK 2836/17, CBOSA; 5 listopada 2019 r., II GSK 3015/17, CBOSA. Może to pozwolić wyeliminować groźbę rozbieżności w orzecznictwie, a w konsekwencji potrzebę podejmowania uchwały przez NSA, stosownie do art. 15 § 1 pkt 2 p.p.s.a.

38 Zob. T. Dauerman, Stypendia sportowe ustanawiane przez jednostki samorzqdu terytorialnego, „Finanse Komunalne" 2017, nr 7-8, s. 16.

39 "Jeżeli coś wygląda jak kaczka, chodzi jak kaczka, pływa jak kaczka i kwacze jak kaczka, to jest to najprawdopodobniej kaczka".
} 
administracyjną. I tak jest w analizowanym przypadku. Naczelny Sąd Administracyjny w komentowanym wyroku nie przedstawił żadnej rodzajowej różnicy. Aby podważyć wskazane stanowisko w ramach wykładni systemowej, sąd ten powinien był tymczasem wykazać, że akt w sprawie przyznania stypendium sportowego nie posiada cech, które implikowałyby stosowanie do jego wydania przepisów k.p.a. (z mocy jego art. 1 pkt 1 k.p.a.), wobec czego znajdują one zastosowanie w przypadku aktów ministra na mocy przepisu szczególnego w postaci art. 32 ust. 5 ustawy o sporcie, zaś brak jego odpowiednika w odniesieniu do aktów organów jednostek samorządu terytorialnego nie pozwala traktować ich jako decyzji administracyjnej. Jak wspomniano, NSA tego nie uczynił, co zresztą z uwagi na tożsamość cech aktów stypendium ministerialnego i samorządowego, nie wydaje się, aby było możliwe do wykonania. W konsekwencji sąd zobowiązany był dokonać tu wykładni z podobieństwa aktów, nie zaś z przeciwieństwa norm, co doprowadziłoby go do odmiennych wniosków niż przedstawione w wyroku.

4. Zwrócić kolejno należy uwagę, że w myśl art. 31 ust. 3 ustawy o sporcie, organ stanowiący jednostki samorządu terytorialnego określa "szczegółowy" tryb przyznawania i pozbawiania stypendiów sportowych, nagród i wyróżnień. Posłużenie się przez ustawodawcę zwrotem „szczegółowy” oznacza, że regulacja ustawowa określa ogólny tryb. Lektura ustawy o sporcie unaocznia jednak, że brak jest w niej regulacji dotyczących procedury przyznawania stypendiów sportowych, nagród i wyróżnień przez jednostki samorządu terytorialnego. Oznacza to, że wynika ona z innego aktu. De lege lata jedynym aktem normatywnym, który będzie w tym zakresie odpowiedni, pozostaje kodeks postępowania administracyjnego.

W ten sposób dochodzimy do jednego z istotniejszych problemów, nie dość omówionego w nauce prawa. Mianowicie powstaje pytanie, czy dopuszczalne jest rozwiązanie, w którym akt podustawowy wprowadza modyfikacje i odmienności w konkretnej kategorii spraw w odniesieniu do regulacji kodeksu postępowania administracyjnego (postępowanie administracyjne szczególne).

Jak się wydaje, jeżeli ustawa zawiera delegację do uregulowania trybu (postępowania) w danej kategorii spraw w akcie podustawowym - rozporządzeniu, akcie prawa miejscowego, a nawet niekiedy w akcie zakładu administracyjnego (np. cieszącej się wynikającą z art. 70 ust. 5 Konstytucji autonomią uczelni) ${ }^{40}$ - to właśnie norma szczególna derogująca normę ogólną wynikającą z kodeksu postępowania administracyjnego jest tworzona przez ów równy w hierarchii źródeł prawa przepis upoważniający, w związku z mieszczącymi się w granicach zawartego w nim upoważnienia przepisami podustawowymi. Tym samym norma ustawowa kodeksowa nie jest wypierana przez normę podustawową ${ }^{41}$ (lex inferiori non derogat legi superiori), lecz przez normę tej

\footnotetext{
40 Zob. wyrok NSA z dnia 12 kwietnia 2016 r., I OSK 2929/15, OSP 2017, z. 6, poz. 55, z glosą P. Dańczaka i A. Jakubowskiego.

41 Co byłoby niezgodne z zasadą lex superior derogat legi inferiori - K.J. Kaleta, A. Kotowski, Podstawy prawoznawstwa, Warszawa 2019, s. 191; T. Chauvin, T. Stawecki, P. Winczorek, Wstęp do prawoznawstwa, Warszawa 2019, s. 151; L. Morawski, Wykładnia w orzecznictwie sq̨dów. Komentarz, Toruń 2002, s. 348, s. 352-353; por. K. Ziemski, Rola i miejsce reguł kolizyjnych w procesie dekodowania tekstu
} 
samej rangi pozostającą w związku z regulacją podustawową. Nie dochodzi zatem do naruszenia w wykładni reguły kolizyjnej lex superior derogat legi inferiori, a zachowana zostaje reguła lex specialis derogat legi generali. Odpowiedź na zadane pytanie jest wobec tego twierdząca. Rzecz jasna, nie dotyczy to sytuacji, gdy norma jest współtworzona przez przepis podustawowy wykraczający poza obszar upoważnienia ustawowego, albowiem w tym zakresie nie uzyskuje rangi hierarchicznie równej normom kodeksu postępowania administracyjnego, wobec czego, zgodnie z regułą lex inferiori non derogat legi superiori, nie może ich zastąpić. Nie budzi też wątpliwości, że wywiedziona z przepisów upoważniającego i wykonawczego norma, uznawana za normę rangi ustawowej, nie może naruszać norm konstytucyjnych.

Przedstawiony model wykładni systemowej i stosowania reguł kolizyjnych znalazł odbicie także w praktyce sądów administracyjnych ${ }^{42}$, jak też zdaje się być dopuszczany przez teorię prawa. Jak stwierdza bowiem Leszek Leszczyński, wyjątkiem od ogólnych reguł wykładni hierarchicznej jest "sytuacja upoważnienia do konkretyzacji przepisu wyższego hierarchicznie przez przepis o niższej mocy prawnej. Przepis wydany w wyniku delegacji ma wówczas charakter regulacji szczególnej, a konkretyzacja może prowadzić do korekty zakresu zastosowania czy normowania wyrażonych w przepisie hierarchicznie wyższym. (...) Zakres tej korekty w przypadku delegacji kompetencji prawodawczych może być jednak rozległy i istotnie wpływać na zrekonstruowany wzór zachowania"43.

Przyjęte zapatrywanie ma walor porządkujący, uelastyczniający i harmonizujący ${ }^{44}$. $Z$ jednej strony, pozwala nie tylko samemu ustawodawcy dostosowywać procedurę do potrzeb danej kategorii spraw, z drugiej - wymusza, aby w zakresie nieokreślonym przepisami szczególnymi - choćby wydanymi na podstawie ustawowej przepisami niższymi w hierarchii źródeł prawa - znajdowały zastosowanie regulacje kodeksowe. Umożliwia to, z jednej strony, uniknięcie luki prawnej, z drugiej - stwarza mechanizm mobilizujący do dokładnego konstruowania regulacji szczególnych. Ich brak lub niezupełność nie będą bowiem poszerzały w danych sprawach dyskrecjonalności organu, lecz wprost przeciwnie - będą go wiązały reżimem kodeksowym. Rozwiązanie to

prawnego, RPEiS 1978, z. 2, s. 7; K. Opałek, J. Wróblewski, Zagadnienia teorii prawa, Warszawa 1969, s. $101-102$.

42 Zob. wyroki NSA z dnia 28 sierpnia 2007 r., I OSK 1801/06 i I OSK 1802/06, CBOSA.

43 L. Leszczyński, Wykładnia systemowa przepisów prawa administracyjnego [w:] System Prawa Administracyjnego, t. 4, Wykładnia w prawie administracyjnym, red. R. Hauser, Z. Niewiadomski, A. Wróbel, Warszawa 2015, s. 249. Autor ten zauważa, że „w przypadku przepisów tzw. blankietowych, upoważniających do wydania innych przepisów, zwykle te ostatnie będą występować jako przepisy uzupełniające wzór podstawowy, chociaż skala uzupełniania może być różna i obejmować także składniki istotne. (...) Dotyczy to także tzw. delegacji ustawowych, mających istotne znaczenie dla stosowania prawa administracyjnego przez organy administracji. Z racji konkretności wzorów w aktach wykonawczych może mieć tu miejsce funkcjonalne odwrócenie hierarchii, co prowadzi do uwzględnienia przede wszystkim przepisów rozporządzenia, a nie bardziej ogólnej (i wymagającej większego wysiłku interpretacyjnego) ustawy" - ibidem, s. 244, por. też s. 243, s. 245-247, s. 250.

44 Por. Z. Kmieciak [w:] Kodeks..., s. 44, który akcentuje uniwersalny charakter k.p.a. oraz jego funkcję porządkującą i projektującą. 
odpowiada w rezultacie wymogom państwa prawnego ${ }^{45}$. Uniemożliwia ucieczkę od procedury właściwą dla państwa policyjnego, narażającą jednostki na arbitralność organów władzy publicznej.

Odnosząc powyższe do analizowanej sprawy, art. 31 ust. 3 ustawy o sporcie nadaje wydanej na jego podstawie regulacji prawa miejscowego charakteru prawa szczególnego, mającego pierwszeństwo przed prawem powszechnie obowiązującym ogólnym ${ }^{46}$ w postaci przepisów k.p.a. Odrębności muszą być jednak sformułowane precyzyjnie ${ }^{47}$, gdyż w razie wątpliwości lub luki znajdzie zastosowanie regulacja ogólna k.p.a.

5. Komentowany wyrok daje okazję do jeszcze jednego spostrzeżenia ogólniejszej natury. Wypracowane w nauce koncepcje kwalifikowania danego działania jako decyzji administracyjnej zdają się częstokroć upadać w konfrontacji z praktyką. Lektura niektórych orzeczeń rodzi wprost wątpliwość, czy sąd nie kierował się maksymą video meliora proboque, deteriora sequor (łac. $)^{48}$ - widzi i pochwala spójną i gwarancyjną koncepcję materialną decyzji administracyjnej, jednak w konkretnych sprawach uznaje ją (niezasadnie w mojej ocenie) za prowadzącą do zbytniego sformalizowania postępowania czy niepozwalającą uwzględnić specyfiki określonej kategorii spraw. Stąd woli uznać dane rozstrzygnięcie za wolny od reżimu k.p.a. (i wynikających z tego kodeksu wzorców kontroli) „inny akt”, o którym mowa w art. 3 § 2 pkt 4 p.p.s.a., lub zgoła traktować je za bliżej nieokreśloną formę nieobjętą właściwością sądów administracyjnych, niż zmierzyć się z trudem jego kontroli i uzgodnienia z wymogami k.p.a. Ta preferencja pojawia się w szczególności w sytuacjach nowych (nieprzetartych orzeczniczo), nietypowych, pozbawionych określenia wprost przez ustawodawcę jako właściwej formy decyzji administracyjnej, w których do tego sam organ kształtuje swój akt tak, aby zewnętrznie (budową) nie przypominał decyzji administracyjnej. Rośnie w konsekwencji ryzyko błędnej kwalifikacji, która może nieść daleko idące konsekwencje proceduralne dla organu. Psychologicznie zrozumiałe jest, że w tym stanie rzeczy składy orzekające mogą się kusić na rozwiązania pozwalające uniknąć kategorycznego przypisania danego aktu do kategorii decyzji administracyjnych ${ }^{49}$. Być może owa wizja - wójta gminy bez zbędnych formalności przyznającego ustnie stypendium i ściskającego dłonie honorowanych sportowców - zwiodła także w glosowanej sprawie. Ta ucieczka od formy decyzji administracyjnej ${ }^{50}$ trudna jest jednak do zaakceptowania.

45 Por. wyrok SN z dnia 18 listopada 1993 r., III ARN 49/93, OSNCP 1994, nr 9, poz. 181; B. Adamiak, Zagadnienie domniemania..., s. 16.

46 Por. B. Wojciechowski, Reguły kolizyjne i inferencyjne w interpretacji prawa administracyjnego [w:] System Prawa Administracyjnego, t. 4..., s. 383.

47 Zob. J. Borkowski, Postępowanie administracyjne ogólne i szczególne [w:] Księga pamiq̨tkowa profesora Eugeniusza Ochendowskiego, Toruń 1999, s. 77.

48 "Widzę i pochwalam lepsze, podążam za gorszym" - Owidiusz, Metamorfozy, rozdział VII, wers 20-21.

49 A. Zieliński w nieco innym kontekście określił to jako „primum spylandum est” - por. A. Zieliński, Prawo do sqqdu a struktura sqdownictwa, PiP 2003, z. 4, s. 21.

50 Zob. J. Zimmermann, Prawo administracyjne, Warszawa 2010, s. 292; C. Martysz [w:] idem, G. Łaszczyca, A. Matan, Kodeks..., s. 30. 
Z tego względu zaaprobować należy orzeczenia idące $w$ kierunku przeciwnym do glosowanego, niedające się zwieść organom administracyjnym pragnącym zrzucić pracochłonne, lecz zabezpieczające prawa obywateli, więzy kodeksu. Do tego nurtu zaliczyć można chociażby wydany zaledwie miesiąc przed komentowanym - wyrok $^{51}$ NSA z lutego 2019 r. W szczegółowym uzasadnieniu sąd wykazał, że sprawa dotycząca przyznania nagrody za odkrycie lub przypadkowe znalezienie zabytku archeologicznego jest sprawą indywidualną (sprawą administracyjną), o której mowa w art. 1 pkt 1 k.p.a., podlegającą załatwieniu w formie decyzji administracyjnej, gdyż sposób jej załatwienia odpowiada właśnie materialnej koncepcji decyzji administracyjnej, a ponadto za taką kwalifikacją przemawia prawo do procesu administracyjnego. Zdaje się zresztą, że przedstawione w komentowanym orzeczeniu zapatrywanie odnośnie charakteru rozstrzygnięcia w przedmiocie przyznania stypendium sportowego przez organ jednostki samorządu terytorialnego - nie przyjęło się w samym Naczelnym Sądzie Administracyjnym. Nie podzielił go bowiem NSA w zapadłych później wyrokach ${ }^{52}$ z sierpnia oraz z listopada 2019 r., gdyż - jak skonstatował w ostatnim z nich - rozstrzygnięcie w omawianym przedmiocie „jest to indywidualne i władcze działanie organu jednostki samorządu terytorialnego (...), a więc decyzja w rozumieniu k.p.a.", na rzecz którego to poglądu w ocenie składu orzekającego „przemawia i to, że tylko w ramach takiej formy działania prawa strony (stypendysty) są najpełniej chronione". Wypada wyrazić nadzieję, że właśnie takie rozumowanie w siódmej dekadzie obowiązywania k.p.a. stanie się wreszcie konsekwentnie realizowanym w praktyce modelem.

\section{Literatura}

Adamiak B., Prawo do procesu na drodze administracyjnej jako gwarancja realizacji zasady demokratycznego państwa prawnego [w:] Instytucje procesu administracyjnego i sq̨dowoadministracyjnego. Księga jubileuszowa dedykowana Prof. nadzw. dr hab. Ludwikowi Żukowskiemu, red. J. Posłuszny, Z. Czarnik, R. Sawuła, Przemyśl-Rzeszów 2009.

Adamiak B., Prawo do procesu w świetle regulacji prawa procesowego administracyjnego [w:] System Prawa Administracyjnego t. 9, Prawo procesowe administracyjne, red. R. Hauser, Z. Niewiadomski, A. Wróbel, Warszawa 2017.

Adamiak B., Zagadnienie domniemania formy decyzji administracyjnej [w:] Podmioty administracji publicznej i prawne formy ich działania. Studia i materiały z Konferencji Naukowej Poświęconej Jubileuszowi 80-tych urodzin Profesora Eugeniusza Ochendowskiego, Toruń 2005.

Adamiak B., Borkowski J., Glosa do wyroku z 21 lutego 1994 r., I SAB 54/93, "Orzecznictwo Sądów Polskich"1995, z. 11, poz. 221.

Borkowski J., Adamiak B., Kodeks postępowania administracyjnego. Komentarz, Warszawa 2019.

Borkowski J., Decyzja administracyjna, Warszawa 1970.

Borkowski J., Decyzja administracyjna, Łódź - Zielona Góra 1998.

\footnotetext{
51 Wyrok NSA z dnia 13 lutego 2019 r., II OSK 731/17, ONSAiWSA 2020, nr 2, poz. 20.

52 Wyroki NSA z dnia: 28 sierpnia 2019 r., II GSK 2836/17, CBOSA; oraz 5 listopada 2019 r., II GSK 3015/17, CBOSA.
} 
Borkowski J., Postępowanie administracyjne ogólne i szczególne [w:] Księga pamiq̨tkowa profesora Eugeniusza Ochendowskiego, Toruń 1999.

Biernat S., Glosa do wyroku NSA z 31 sierpnia 1984 r., SA/Wr 430/84 „, Orzecznictwo Sądów Polskich" 1986, z. 9-10, poz. 176.

Bogusz M., Zaskarżenie decyzji administracyjnej do Naczelnego Sądu Administracyjnego, Warszawa 1997.

Chauvin T., Stawecki T., Winczorek P., Wstęp do prawoznawstwa, Warszawa 2019.

Dauerman T., Stypendia sportowe ustanawiane przez jednostki samorzqdu terytorialnego „Finanse Komunalne" 2017, nr 7-8.

Gołaszewski P., Wąsowski K. [w:] Kodeks postępowania administracyjnego. Komentarz, red. R. Hauser, M. Wierzbowski, Warszawa 2018.

Iserzon E. [w:] idem, Starościak J., Kodeks postępowania administracyjnego. Komentarz, Warszawa 1961.

Janowicz Z., Kodeks postępowania administracyjnego. Komentarz, Warszawa-Poznań 1987.

Leszczyński L., Wykładnia systemowa przepisów prawa administracyjnego [w:] System Prawa Administracyjnego, t. 4, Wykładnia w prawie administracyjnym, red. R. Hauser, Z. Niewiadomski, A. Wróbel, Warszawa 2015.

Kaleta K.J., Kotowski A., Podstawy prawoznawstwa, Warszawa 2019.

Kędziora R., Kodeks postępowania administracyjnego. Komentarz, Warszawa 2017.

Klonowski K. [w:] Kodeks postępowania administracyjnego. Komentarz, red. H. Knysiak-Sudyka, Warszawa 2019.

Kmieciak Z. [w:] Kodeks postępowania administracyjnego. Komentarz, red. Z. Kmieciak, W. Chróścielewski, Warszawa 2019.

Kmieciak Z., W poszukiwaniu modelu postępowania odpowiadającego naturze administracji publicznej, PiP 2015, z. 11.

Materiały do nauki prawa administracyjnego, red. M. Kulesza, Warszawa 1985.

Martysz C. [w:] idem, G. Łaszczyca, A. Matan, Kodeks postępowania administracyjnego. Komentarz, t. 1, Art. 1-104, Warszawa 2010.

Morawski L., Wykładnia w orzecznictwie sądów. Komentarz, Toruń 2002.

Opałek K., Wróblewski J. , Zagadnienia teorii prawa, Warszawa 1969.

Orzechowski R. [w:] Kodeks postępowania administracyjnego. Komentarz, red. J. Borkowski, Warszawa 1985.

Owidiusz, Metamorfozy, rozdział VII, wers 20-21.

Starościak J., Prawne formy i metody działania administracji [w:] System Prawa Administracyjnego, t. 3, red. T. Rabska, J. Łętowski, Wrocław 1978.

Taras W., Glosa do wyroku SN z dnia 28 listopada 1990 r., III ARN 30/90, „Orzecznictwo Sądów Polskich"1992, z. 5.

Tarno J.P., Glosa do uchwały NSA z 12 grudnia 2005 r., II OPS 4/05, ,Zeszyty Naukowe Sądownictwa Administracyjnego" 2006, nr 1.

Wojciechowski B., Reguły kolizyjne i inferencyjne $w$ interpretacji prawa administracyjnego [w:] System Prawa Administracyjnego, t. 4, Wykładnia w prawie administracyjnym, red. R. Hauser, Z. Niewiadomski, A. Wróbel, Warszawa 2015.

Wróbel A. [w:] idem, M. Jaśkowska, Kodeks postępowania administracyjnego. Komentarz, Warszawa 2016.

Wyszomirski Ł.M., Sądowa kontrola innych niż decyzje i postanowienia aktów i czynności z zakresu administracji publicznej, Warszawa 2018. 
Zieliński A., Prawo do sq̨du a struktura sq̨downictwa, „Państwo i Prawo” 2003, z. 4.

Ziemski K.M., Indywidualny akt administracyjny jako forma prawna działania administracji, Poznań 2005.

Ziemski K., Indywidualny akt administracyjny - jego istota [w:] System Prawa Administracyjnego, t. 5, Prawne formy działania administracji, red. R. Hauser, Z. Niewiadomski, A. Wróbel, Warszawa 2013.

Ziemski K., Rola i miejsce reguł kolizyjnych w procesie dekodowania tekstu prawnego, „Ruch Prawniczy, Ekonomiczny i Socjologiczny" 1978, z. 2.

Zimmermann J., Prawo administracyjne, Warszawa 2010.

\section{Streszczenie}

\section{Aleksander Jakubowski}

Test decyzji administracyjnej i dopuszczalność modyfikacji trybu jej wydawania przepisami podustawowymi

Naczelny Sąd Administracyjny stwierdził, że rozstrzygnięcie w sprawie przyznania stypendium sportowego przez jednostkę samorządu terytorialnego nie jest decyzją administracyjną wydawaną w trybie kodeksu postępowania administracyjnego. W glosie przedstawiono krytyczną analizę tego stanowiska. Akt ten rozstrzyga o prawach indywidualnego podmiotu w sprawie stypendium finansowanego przez samorząd terytorialny. Posiada zatem cechy kwalifikujące go jako decyzję administracyjną. Na kanwie sprawy autor konstruuje test decyzji administracyjnej.

\section{Summary}

\section{Aleksander Jakubowski}

Administrative decision test and the admissibility to modify the procedure for issuance a decision by sub-statutory legal acts

The Supreme Administrative Court stated that the decision on granting a sport scholarship by a local government unit is not an administrative decision issued under the Code of Administrative Procedure. The commentary presents a critical analysis of this statement. The act analyzed by the Court decides about rights of an individual in regard to a sport scholarship financed by local government. Therefore, it has features which justify its qualification as an administrative decision. On the basis of this case, the author proposes an administrative decision test.

Słowa kluczowe: decyzja administracyjna, postępowanie administracyjne, stypendium sportowe

Key words: administrative decision, administrative procedure, sport scholarship 